\title{
Synergism of aromatic amines and benzo[a]pyrene in induction of Ah receptor-dependent genes
}

\author{
Alexandra Borza $\cdot$ Sabine Plöttner $\cdot$ Alexander Wolf $\cdot$ Claudia Behm $\cdot$ Silvia Selinski $\cdot$ \\ Jan G. Hengstler · Peter H. Roos · Hermann M. Bolt • Jürgen Kuhlmann • \\ Wolfram Föllmann
}

Received: 14 October 2008 / Accepted: 15 October 2008 / Published online: 7 November 2008

(C) The Author(s) 2008. This article is published with open access at Springerlink.com

\begin{abstract}
Aromatic amines have been shown to cause bladder cancer. However, epithelial cells of the urinary bladder, cells of origin of bladder cancer, may be exposed to numerous substances besides aromatic amines. In the present study, we analysed possible interactions between the aromatic amines 4-aminobiphenyl (4-ABP) as well as 2-naphthylamine (2-NA) and the polycyclic aromatic hydrocarbon benzo[a]pyrene $(\mathrm{B}[\mathrm{a}] \mathrm{P})$. For this purpose we incubated primary porcine urinary bladder epithelial cells (PUBEC) with concentrations of 1 to $50 \mu \mathrm{M} 4-\mathrm{ABP}$ with and without coexposure to $\mathrm{B}[\mathrm{a}] \mathrm{P}$. As expected $\mathrm{B}[\mathrm{a}] \mathrm{P}$ increased mRNA expression of cytochrome P450 1A1 (CYP1A1), whereas 4-ABP had no effect. However, when co-exposed 4-ABP enhanced the induction of CYP1A1 by B[a]P. This result was confirmed by Western blot analysis of CYP1A1 protein
\end{abstract}

A. Borza, S. Plöttner, A. Wolf, C. Behm have contributed equally to this work.

J. Kuhlmann is deceased.

A. Borza $\cdot$ A. Wolf $\cdot$ J. Kuhlmann

Max-Planck Institut für molekulare Physiologie,

Otto-Hahn-Str. 11, 44227 Dortmund, Germany

S. Plöttner · C. Behm · S. Selinski · J. G. Hengstler · P. H. Roos ·

H. M. Bolt · W. Föllmann ( $\varangle)$

Leibniz Research Centre for Working Environment and Human Factors, Institut für Arbeitsphysiologie an der Universität Dortmund (IfADo),

Ardeystr. 67, 44139 Dortmund, Germany

e-mail: foellmann@ifado.de

Present Address:

S. Plöttner

BGFA-Forschungsinstitut für Arbeitsmedizin

der Deutschen Gesetzlichen Unfallversicherung,

Institut der Ruhr-Universität Bochum,

Bürkle-de-la-Camp-Platz 1, 44789 Bochum, Germany expression. A similar effect as for CYP1A1 was also observed for cyclooxygenase-2 (COX-2) and UDP-glucuronosyltransferase 1 (UGT1). Next, we studied co-exposures of 2-NA and B[a]P. Similar as for 4-ABP also 2-NA enhanced $\mathrm{B}[\mathrm{a}] \mathrm{P}-$ mediated induction of CYP1A1. Our results demonstrate that some aromatic amines may enhance the influence of $\mathrm{B}[\mathrm{a}] \mathrm{P}$ on $\mathrm{Ah}$ receptor-dependent genes.

Keywords Bladder cancer - Combination effects . Aromatic amines - Polycyclic aromatic hydrocarbons . Xenobiotic metabolising enzymes · CYP1A1 induction . PUBEC

\section{Introduction}

Consumption of tobacco products is one of the most dominant contributions in life-style based induction of human cancer (Wu et al. 2006; Lovreglio et al. 2006). Beside its role as a cause of lung cancer, smoking is considered as the most prominent, non-occupational risk factor for the development of bladder cancer (IARC 1986, 2004; Kim et al. 2007). Tobacco products are held responsible for $\sim 30 \%$ of all cancer deaths in the developed countries (Hecht 2003). While lung cancer is the most predominant malignant tumour associated with smoking, several other cancer diseases show a causal relationship with tobacco consumption (Vineis et al. 2004a). An association between smoking and bladder cancer has been deduced by case-control and cohort studies (Brennan et al. 2000, 2001). In particular, aromatic amines have been in the focus as the putative causer of this type of neoplasia (Vineis et al. 2004b). Cigarette smoke consists of 4,800 identified compounds (Green and Rodgman 1996), including more than 70 chemicals with proven, probable or possible carcinogenic effects in 
human (Smith et al. 2003). Unfortunately, little is known about interactions of these substances.

To elucidate the molecular mechanisms of tobacco smoke-induced bladder cancer in a model system with a high physiological relevance and with an almost unlimited access to the biological materials, we utilised the wellestablished porcine based primary cell culture system for our studies (PUBEC). This represents an in vitro system of epithelial bladder cells that maintains in vivo-like metabolic competence even after long-time cultivation (Guhe et al. 1996). The cells have no specific genetic defects, as it is the case for all immortalised cell lines. The porcine bladder epithelium closely matches the human organ and its physiological properties (Föllmann et al. 2000a; Guhe et al. 1996; Guhe and Föllmann 1994). It is available as a byproduct of industrial meat production.

Aromatic amines and polycyclic aromatic hydrocarbons represent two major classes of carcinogens to which bladder epithelial cells are exposed. In the present study, we used 4-ABP and B[a]P as model substances and studied possible interactions concerning induction of CYP1A1, COX-2 and UGT1. We report that 4-ABP that alone did not influence levels of enzyme expression clearly enhanced the enzyme inducing capacity of $\mathrm{B}[\mathrm{a}] \mathrm{P}$.

\section{Materials and methods}

\section{Materials}

F-12 (Ham) Nutrient Mixture with GlutaMAX ${ }^{\mathrm{TM}}$, penicillin/streptomycin, amphotericin B, transferrin (bovine, holo), phosphate buffered saline (PBS), trypsin/EDTA, and non-essential amino acids, Superscript ${ }^{\mathrm{TM}}$ II Reverse Transcriptase, and Trizol ${ }^{\circledR}$ reagent were purchased from Invitrogen (Karlsruhe, Germany). Insulin (bovine, $\mathrm{Zn}$ salt) was obtained from Biochrom KG (Berlin, Germany); $\mathrm{d}(+)$ glucose monohydrate was delivered by Merck (Darmstadt, Germany). Hydrocortisone, benzo[a]pyrene, 4-aminobiphenyl, 2-naphthylamine, non-labelled monoclonal mouse anti- $\beta$-actin antibody (clone AC-15, IgG1), biotinylated goat anti-mouse $\operatorname{IgG}$ antibody, peroxidase-labelled goat anti-mouse antibody, and streptavidin-peroxidase (from Streptomyces avidinii) were from Sigma-Aldrich (Taufkirchen, Germany). Long ${ }^{\mathrm{TM}}$ epidermal growth factor (EGF, media grade) was obtained from IBT GmbH (Reutlingen, Germany). Collagen $\mathrm{R}$ was from Serva (Heidelberg, Germany). Protease inhibitor "complete" tablets were from Roche (Mannheim, Germany). ECL ${ }^{\mathrm{TM}}$ detection reagent and Hyperfilm ${ }^{\mathrm{TM}}$ ECL $^{\mathrm{TM}}$ were obtained from GE Healthcare Life Sciences (Munich, Germany). Monoclonal mouse anti-CYP1A1 IgG1 (MAb1A3-03) was purchased from CYP2000 (Bochum, Germany).
Cell isolation and cell culture

Porcine urinary bladder epithelial cells (PUBEC) were isolated from urine-filled bladders of freshly slaughtered barrows of regional provenance (mongrels from German land pig, German or Belgian noble pig, Piétrain and Duroc). The cells were cultured under serum-free conditions according to Guhe and Föllmann (1994), with minor modifications as described earlier (Wolf et al. 2005; Plöttner et al. 2008a). Urinary bladders were obtained from slaughtered pigs immediately after opening of the abdominal wall about 15 20 min after slaughter at the local slaughterhouse of Lünen, Germany. The organs were transferred to the laboratory in ice-cold phosphate buffered saline (PBS) supplemented with $100 \mu \mathrm{g} / \mathrm{ml}$ streptomycin, $100 \mathrm{U} / \mathrm{ml}$ penicillin, and $2.5 \mu \mathrm{g} / \mathrm{ml}$ amphotericin. Under sterile conditions, the bladders were opened and the epithelial mucosa of each bladder was carefully scraped from the underlying muscle layer with a sterile glass slide and transferred into PBS. Isolated cells were centrifuged at $50 \times g$ for $5 \mathrm{~min}$. The supernatant was discarded, and the cell pellet was resuspended in PBS and centrifuged again. Overall, cells were washed at least three times to remove cell debris. After the last washing step, the resulting cell pellet was resuspended with culture medium. For cell culture, the pellets of five bladders were pooled, and the cell number was determined. Viability was assessed by trypan blue exclusion $(900 \mu \mathrm{l} 0.1 \%$ trypan blue $+100 \mu$ cell suspension). F-12 (Ham) "Nutrient Mixture" with GlutaMAX ${ }^{\mathrm{TM}}$ supplemented with $100 \mathrm{U} / \mathrm{ml}$ penicillin, $100 \mu \mathrm{g} / \mathrm{ml}$ streptomycin, $1.25 \mu \mathrm{g} / \mathrm{ml}$ amphotericin B, $5 \mu \mathrm{g} / \mathrm{ml}$ bovine transferrin, $0.1 \mathrm{mM}$ non-essential amino acids, $10 \mu \mathrm{g} / \mathrm{ml}$ insulin, $2.7 \mathrm{mg} / \mathrm{ml}$ glucose, $1 \mu \mathrm{g} / \mathrm{ml}$ hydrocortisone, and $20 \mathrm{ng} / \mathrm{ml}$ Long ${ }^{\mathrm{TM}}$ EGF was used as culture medium. This medium, with hydrocortisone and low calcium, was chosen to favour the selective growth of the epithelial cells and to avoid an overgrowth of cultured PUBEC by possible contamination with fibroblasts. Additionally, culture flasks were coated with collagen type I. For incubation experiments to assess changes in gene and protein expressions as well as cytotoxicity, on the day of isolation $12 \times 10^{6}$ PUBEC were suspended in $10 \mathrm{ml}$ serum-free culture medium and seeded in $75 \mathrm{~cm}^{2}$ culture flasks (coated with $200 \mu \mathrm{g}$ collagen). PUBEC were cultured under standard cell culture conditions in a humidified incubator at $5 \%$ $\mathrm{CO}_{2}$ and $37^{\circ} \mathrm{C}$ atmosphere according to Guhe and Föllmann (1994). Medium was changed after $24 \mathrm{~h}$ culture to remove non-attached and dead cells. On day 2 after isolation, cells were removed from the substrate by 5-8 min treatment with $0.25 \%$ trypsin $/ 1 \mathrm{mM}$ EDTA. The reaction was stopped by adding equal volumes of culture medium with $40 \%(\mathrm{v} / \mathrm{v})$ fetal calf serum (final concentration $20 \%$ ). After centrifugation $(200 \times g, 5 \mathrm{~min})$ the supernatant was discarded and the cell pellet was resuspended in fresh 
culture medium. As PUBEC tend to form clots, after resuspension cell aggregates were allowed to sediment to the bottom of the centrifugation tube for a few minutes. The supernatant with single cells was then transferred into a new tube and cells were counted before seeding in defined densities into new cell culture dishes $\left(2 \times 10^{6}\right.$ cells in $5 \mathrm{ml}$ in $25 \mathrm{~cm}^{2}$ flasks and 20,000 cells per $200 \mu \mathrm{l}$ per well in $96-$ well microtiter plates). For the micronucleus test, $10^{6}$ freshly isolated cells were seeded into $25 \mathrm{~cm}^{2}$ flasks. Culture medium was changed on day 1 after isolation, and cells were not passaged as for the other experiments.

\section{Cytotoxicity assay}

Cytotoxicity was assessed by means of neutral red (NR) uptake measurement. PUBEC were seeded in 96-well microtiter plates in serum-free medium, and evaluated as described previously (Föllmann et al. 2000b, 2007; Wolf et al. 2005). In brief, 20,000 PUBEC in $200 \mu \mathrm{l}$ culture medium were seeded per well in 96-well culture plates. After $24 \mathrm{~h}$ culture the medium was withdrawn and PUBEC were incubated for $24 \mathrm{~h}$ with different concentrations of the test substances in serum-free culture medium. Afterwards the incubation medium was withdrawn and substituted by culture medium with neutral red $(0.05 \mathrm{mg} / \mathrm{ml})$, which was pre-incubated at $5 \% \mathrm{CO}_{2}$ and $37^{\circ} \mathrm{C}$ for $17 \mathrm{~h}$. After another incubation period of $3 \mathrm{~h}$ the medium was withdrawn, and the cells were washed five times with PBS and fixed with $0.2 \mathrm{ml}$ fixative (glacial acetic acid/water/ethanol, 1:49:50) per well which brings the dye NR into solution upon 20 min of shaking $(600 \mathrm{rpm})$ on a plate shaker (MTS2, IKA $^{\circledR}$ Labortechnik, Staufen, Germany). Then extinction of NR was measured with a plate photometer (SpectraFluor Plus microplate reader, Tecan, Crailsheim, Germany) at $540 \mathrm{~nm}$. NR uptake was expressed in percent of that of a solvent control (DMSO).

In vitro micronucleus assay

The micronucleus assay with PUBEC was conducted according to Bonacker et al. (2004), based on the method of Matsuoka et al. (1992), with some adaptations for PUBEC. $1 \times 10^{6}$ cells were seeded per $25 \mathrm{~cm}^{2}$ flask (each flask coated with $100 \mu \mathrm{g}$ collagen) in F12 (Ham) medium with supplements (see above). On the next day, the culture medium was changed to remove non-attached cells. After 2 days in culture the medium was removed and replaced by fresh culture medium supplemented with the test substances (dissolved in DMSO), which were added to the cell cultures in volumes equivalent to $1 \%$ of the volume of the culture medium (final DMSO concentration $0.2 \%$ ). After an incubation period of about 1.5 cell cycles $(30 \mathrm{~h}$ for PUBEC, to allow expression of micronuclei adjusted to the popula- tion doubling time of the cells), the medium was removed, and cells were detached by disaggregation with trypsin/ EDTA $(0.05 \%$ trypsin in PBS with $0.02 \%$ ethylenediaminetetraacetic acid). Cells were then subjected to hypotonic conditions with $0.4 \% \mathrm{KCl}$. After centrifugation $(130 \times g$, $10 \mathrm{~min}$ ) the cell pellets were re-suspended in $5 \mathrm{ml}$ ice-cold methanol/acetic acid $(3: 1)$ as fixative for $15 \mathrm{~min}$ at $-20^{\circ} \mathrm{C}$. This fixation step was performed three times. After the last centrifugation, the supernatant was withdrawn, and the cell pellet was resuspended in $0.5 \mathrm{ml}$ fresh fixative. Some drops of the suspension were transferred onto glass slides, and cells were fixed by heat treatment. The slides were stained with acridine orange solution $(0.05 \mathrm{mg} / \mathrm{ml})$ and were examined using a DM LB fluorescence microscope (Leica, Germany, excitation filter 440-490 nm, barrier filter I3, 400× magnification, $50 \mathrm{~W}$ mercury lamp). For each concentration, the number of micronucleated cells out of at least 2,000 cells with well preserved cytoplasm was analysed for micronuclei $(\mathrm{MN})$. The scoring for micronuclei followed published criteria (Countryman and Heddle 1976; Fenech 1993): Only cells with intact cytoplasm, where the micronucleus size was maximally one-third of the main nucleus and showed a similar colour and shape, were counted. Micronucleus-like structures attached the main nucleus of the cell were not scored. Mean values for treated cell cultures were compared with the respective solvent controls. The experiment was repeated at least three times.

\section{Real-time reverse transcription PCR (RT-RT-PCR)}

Total RNA was prepared from untreated PUBEC and PUBEC treated with 4-ABP, B[a]P or binary mixtures of both chemicals with Trizol ${ }^{\circledR}$ reagent (Invitrogen, Karlsruhe, Germany) following the manufacturer's instructions and subjected to DNAse treatment (DNAfree ${ }^{\mathrm{TM}}$, Ambion, Austin, USA). Real-time RT-PCR with on-line detection of fluorescence was performed with a Lightcycler 3 instrument (Roche, Mannheim, Germany). Quantification of CYP1A1, UGT1 and COX-2 was carried out by one-step RT-PCR as previously described in detail (Wolf et al. 2005). Three hundred nanograms of total RNA and $6 \mathrm{nmol}$ of gene specific primers were used in a $20 \mu \mathrm{l}$ reaction (DNA Master SybrGreen I Mix, Roche) in glass vials (Roche, Mannheim, Germany). A two-step RT-PCR protocol was adapted for quantification of CYP1B1 and CYP4B1 and DNA repair genes: $5 \mu \mathrm{g}$ of total RNA was transcribed to cDNA with Superscript ${ }^{\mathrm{TM}}$ II Reverse Transcriptase (Invitrogen) in a 50$\mu l$ reaction. Real-time PCR was carried out with $1 \mu$ l of the cDNA solution and $6 \mathrm{nmol}$ of gene specific primers according to the manufacturer's instructions (LightCycler FastStart DNA MasterPlus SYBR Green I, Roche, Mannheim, Germany). Prior to gene quantification primer specificity was verified for all genes by cloning and sequencing. A melting 
curve analysis was performed with LightCycler 3 Software after each run. Relative quantification of gene expression changes was calculated based on the $2^{-\Delta \Delta C P}$ method (Livak and Schmittgen 2001).

\section{Western blot analysis for CYP1A1}

Western Blot analysis was carried out as described previously (Plöttner et al. 2008b). $2.5 \times 10^{6}$ cells in $25 \mathrm{~cm}^{2}$ flasks were incubated for $24 \mathrm{~h}$ with different concentrations of 4$\mathrm{ABP}$ or 2-NA or co-incubated with 4-ABP or 2-NA and $1 \mu \mathrm{M}$ B[a]P. Afterwards, the incubation medium was withdrawn and PUBEC were washed twice with PBS. Then cells were detached from the substrate by treatment with trypsin/ EDTA and centrifuged for $10 \mathrm{~min}(200 \times g)$. The supernatant was withdrawn and the pellet was frozen in liquid nitrogen and stored at $-80^{\circ} \mathrm{C}$. For preparation of cell homogenates, the cell pellets were thawed slowly on ice and resuspended in $100 \mu \mathrm{l}$ ice-cold homogenization buffer $[0.1 \mathrm{M}$ tris(hydroxymethyl)-aminomethane, $0.1 \mathrm{M} \mathrm{KCl}, 1 \mathrm{mM}$ EDTA. The $\mathrm{pH}$ was adjusted to 7.4 with $\mathrm{HCl}$. To inhibit protease activity, directly before use $23 \mu \mathrm{M}$ 3,5-di-tert-butyl-4hydroxybenzyl alcohol and one tablet "complete" protease inhibitor (Roche, Mannheim, Germany) were added to $50 \mathrm{ml}$ buffer]. The cells were homogenised for $1 \mathrm{~min}$ by a motor-driven pellet pestle (Sigma, Taufkirchen, Germany). Further homogenisation of the cells was done on ice with an ultrasonic disintegrator (Sonoplus HD 200, Bandelin Electronic, Berlin, Germany) at maximum amplitude of $40 \%$ in 5 intervals of sonification (10 s) and cooling on ice (30s). Then, protein content of the cell homogenates was determined and $2 \mu \mathrm{g}$ of the cell homogenates were applied to SDS PAGE followed by transfer to a Protran ${ }^{\circledR}$ nitrocellulose membrane (Whatman Schleicher \& Schuell BioScience, Dassel, Germany). CYP1A1 was detected by the specific monoclonal antibody MAb1A3-03 (mouse IgG1, miniPERM $^{\mathrm{TM}}$ supernatant) diluted 1:300 in PBS, in combination with a biotinylated second antibody (goat anti-mouse IgG, diluted $1: 1,000$ in PBS $+0.1 \%$ Tween $\left.^{\circledR} 20\right)$ and $2 \mu \mathrm{g} / \mathrm{ml}$ streptavidin-peroxidase conjugate (Sigma, Taufkirchen, Germany). For visualisation of the reaction, ECL ${ }^{\mathrm{TM}}$ detection reagent and Hyperfilm ${ }^{\mathrm{TM}} \mathrm{ECL}^{\mathrm{TM}}$ were applied (GE Healthcare Life Sciences, Munich, Germany). Quantitation was achieved with CCD camera digitalised pictures of the stained immunoblots utilising the image analysis software WinCam 2.1 (Cybertech, Berlin, Germany). As reference standard for CYP1A1 detection, liver microsomes from 3methylcholanthrene treated rats (Roos 2002) were utilised. The density values were related to the density of the Western Blot standard and calculated as relative induction per microgram cell lysate divided by the intensity of $1 \mu \mathrm{g}$ Western Blot standard. For loading control, immunoblots were stained according to Liao et al. (2000) with monoclonal anti- $\beta$-actin antibody (clone AC-15, IgG1, Sigma, Taufkirchen, Germany) diluted 1:1,000 in PBS in combination with a peroxidase-labelled goat anti-mouse antibody.

\section{Statistical analysis}

Increased induction of micronuclei in PUBEC by increased 4-ABP concentrations without and in combination with $1 \mu \mathrm{M}$ B[a]P was investigated using a quasi-binomial model with the log link function accounting for overdispersion and variation between PUBEC (Paul and Saha 2007). Williams-type contrasts (Williams 1971) were used to detect a possible concentrations-related trend supposing a monotone trend for increasing 4-ABP concentrations, $1 \mu \mathrm{M}$ $\mathrm{B}[\mathrm{a}] \mathrm{P}$ without $4-\mathrm{ABP}$, and combinations of $1 \mu \mathrm{M} \mathrm{B}[\mathrm{a}] \mathrm{P}$ and increasing 4-ABP concentrations (Hothorn et al. 2008; Hothorn and Gerhard 2008). Adjusted p-values were calculated using the R software packages MASS (Venables and Ripley 2002) and multcomp (Hothorn et al. 2008). After checking the data for unequal variances using the FlignerKilleen test (Conover et al. 1981) general differences between single and combined concentrations of 4-ABP and $\mathrm{B}[\mathrm{a}] \mathrm{P}$ or 2-NA and $\mathrm{B}[\mathrm{a}] \mathrm{P}$, respectively, with respect to the induction of CYP1A1, UGT1 and COX-2 were determined using exact two-sided Kruskal-Wallis tests (Hollander and Wolfe 1999) as sample sizes were small and variances did not show substantial differences. Pair wise exact Wilcoxon rank sum tests (Hollander and Wolfe 1999) were conducted to determine possible increases of induction by combinations of $\mathrm{B}[\mathrm{a}] \mathrm{P}$ and 4-ABP using the $\mathrm{R}$ software package exact RankTests. One-sided tests were used to test for an increase due to single concentrations, two-sided tests were applied in case of combined high concentrations as downturn effects are likely to occur here. In particular, we used two-tailed tests for comparisons of $\mathrm{B}[\mathrm{a}] \mathrm{P}$ combinations with 10 and $50 \mu \mathrm{M} 4-\mathrm{ABP}$ or $10 \mu \mathrm{M} 2-\mathrm{NA}$, respectively. The statistical analysis was performed using the software $\mathrm{R}$ 2.7.1 (R Development Core Team 2008).

\section{Results}

In order to study, whether 4-ABP influences the enzyme inducing effect of $\mathrm{B}[\mathrm{a}] \mathrm{P}$ we used the following experimental setup: cultured primary porcine urinary bladder epithelial cells (PUBEC) were incubated with 1,10 and $50 \mu \mathrm{M}$ 4-ABP alone as well as in combination with $1 \mu \mathrm{M} \mathrm{B}[\mathrm{a}] \mathrm{P}$ (Fig. 1). 4-ABP alone (1, 10 and $50 \mu \mathrm{M})$ did not induce CYP1A1 expression (Fig. 1a). As known from previous studies (Wolf et al. 2005; Plöttner et al. 2008a) $1 \mu \mathrm{M} \mathrm{B}[\mathrm{a}] \mathrm{P}$ caused a clear induction of CYP1A1 mRNA expression. Interestingly, 4-ABP caused a further increase of $\mathrm{B}[\mathrm{a}] \mathrm{P}$ induced enzyme induction (Fig. 1a). 

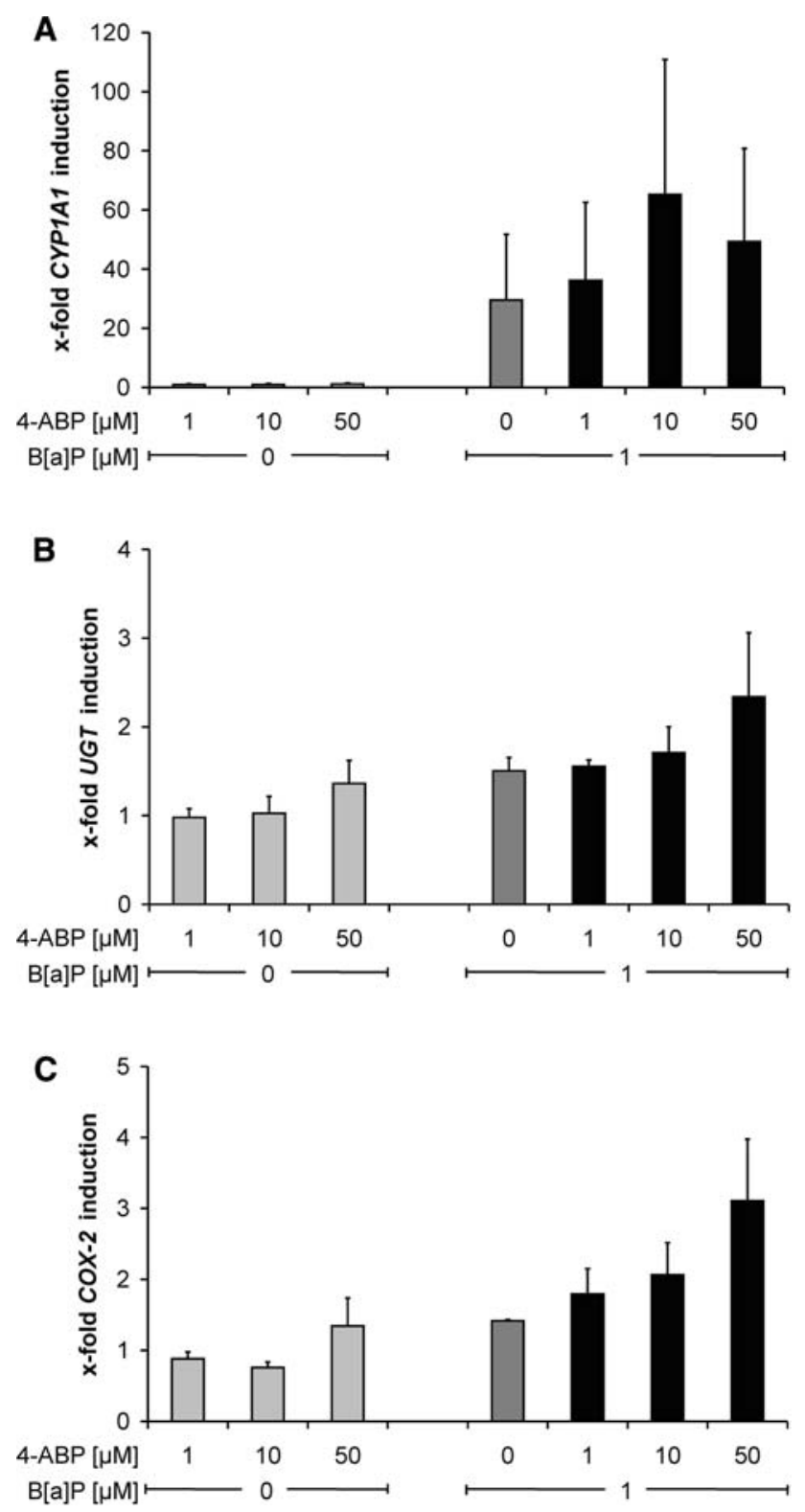

Fig. 1 Relative transcript levels of CYP1A1 (a), of UDP glucuronosyltransferase 1 (UGT1) (b) and of cyclooxygenase 2 (COX-2) (c) in PUBEC treated with 4-ABP alone (left columns), $1 \mu \mathrm{M}$ B[a]P (dark grey column) and with 4-ABP in combination with $1 \mu \mathrm{M} \mathrm{B}[\mathrm{a}] \mathrm{P}$ (black columns). PUBEC were incubated for $24 \mathrm{~h}$ with the indicated concentrations of the test substances and with the solvent. Relative quantification of gene expression changes was calculated based on the $2^{-\Delta \Delta C P}$ method (Livak and Schmittgen 2001). $n=3$, * significant $P \leq 0.05$ (Wilcoxon test, one-sided for $1 \mu \mathrm{M} \mathrm{B}[\mathrm{a}] \mathrm{P}+0,1$ and $3 \mu \mathrm{M} 4-\mathrm{ABP}$, two-sided for $1 \mu \mathrm{M} \mathrm{B}[\mathrm{a}] \mathrm{P}+10$ and $50 \mu \mathrm{M} 4-\mathrm{ABP}$, control $=1 \mu \mathrm{M}$ $\mathrm{B}[\mathrm{a}] \mathrm{P}+0 \mu \mathrm{M} 4-\mathrm{ABP})$

Using the same experimental setup we additionally analysed induction of UGT1 (Fig. 1b) and COX-2 (Fig. 1c). Although 4-ABP alone did not induce transcript levels, it clearly enhanced the effect of $\mathrm{B}[\mathrm{a}] \mathrm{P}$. To confirm the result on the protein level, we performed Western blot analysis of CYP1A1, using a similar experimental setup (Fig. 2).
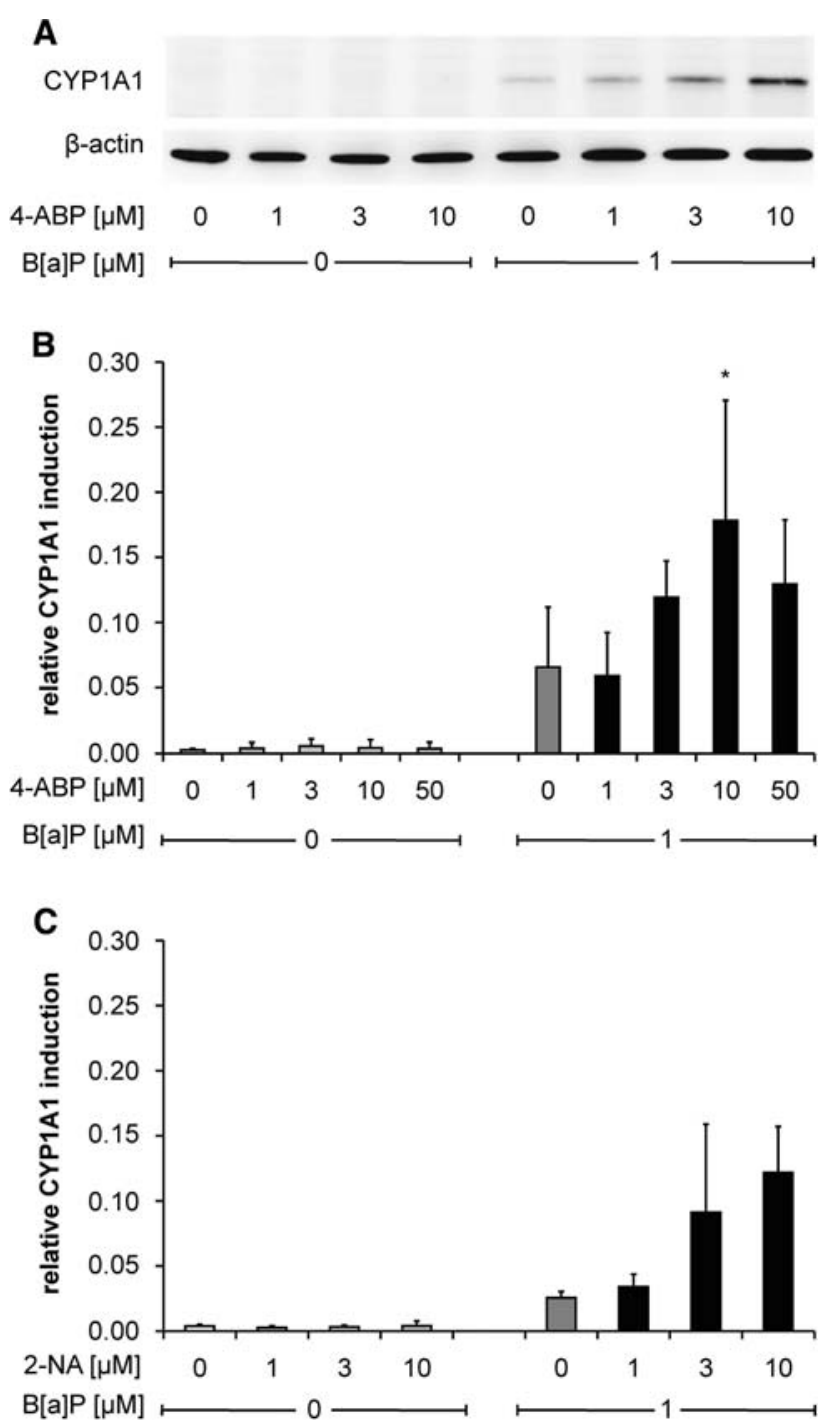

Fig. 2 a Representative immunoblot of CYP1A1 protein induction in PUBEC after treatment with 4-aminobiphenyl (4-ABP), B[a]P and binary mixtures of 4-ABP and $\mathrm{B}[\mathrm{a}] \mathrm{P}$ determined with Western Blot analysis $(2 \mu \mathrm{g}$ protein per lane). b Relative level of CYP1A1 induction in PUBEC after $24 \mathrm{~h}$ treatment with the solvent (0.2\% DMSO, left lane), with 4-aminobiphenyl (4-ABP), B[a]P and binary mixtures of 4-ABP and $\mathrm{B}[\mathrm{a}] \mathrm{P}$. Western Blot signals were normalised by controls from liver microsomes of 3-methylcholanthrene treated rats and induction is shown as relative induction compared to the microsomal standard (see "Materials and methods"). * Significant $P \leq 0.05$ (Wilcoxon test, onesided for $1 \mu \mathrm{M} \mathrm{B}[\mathrm{a}] \mathrm{P}+0,1$ and $3 \mu \mathrm{M}$ 4- $\mathrm{ABP}$, two-sided for $1 \mu \mathrm{M}$ $\mathrm{B}[\mathrm{a}] \mathrm{P}+10$ and $50 \mu \mathrm{M} 4-\mathrm{ABP}$, control $=1 \mu \mathrm{M} \mathrm{B}[\mathrm{a}] \mathrm{P}+0 \mu \mathrm{M} 4-\mathrm{ABP})$, $n=4$; c Relative level of CYP1A1 induction in PUBEC after $24 \mathrm{~h}$ treatment with the solvent $(0.2 \%$ DMSO, left lane), with 2-naphthylamine (2-NA), B [a]P and binary mixtures of 2-NA and B [a]P. Western Blot signals were normalised by controls from liver microsomes of 3-methylcholanthrene treated rats and induction is shown as relative induction compared to the microsomal standard (see "Materials and methods"), $n=2$

Again, 4-ABP alone did not increase CYP1A1 levels but clearly enhanced CYP1A1 induction by $1 \mu \mathrm{M}$ B[a]P (Fig. 2a, b). 
Next, we were interested in the question, whether only 4-ABP enhances enzyme induction capacity of $\mathrm{B}[\mathrm{a}] \mathrm{P}$ or whether this effect can also be observed for other aromatic amines. For this purpose we studied 2-NA using the same experimental schedule as for 4-ABP (Fig. 2c) Interestingly, 2-NA enhanced the effect of $\mathrm{B}[\mathrm{a}] \mathrm{P}$ even more as 4-ABP. Although $10 \mu \mathrm{M} 2-\mathrm{NA}$ alone did not induce CYP1A1 protein, it caused an almost fivefold increase of the effect of B[a]P (Fig. 2c).

Similar experiments were performed to study whether 4-ABP influences B[a]P-induced cytotoxicity (Fig. 3a) as well as micronuclei (Fig. 3b). However, in contrast to enzyme induction, 4-ABP did not significantly influence levels of B[a]P-induced cytotoxicity and micronuclei.
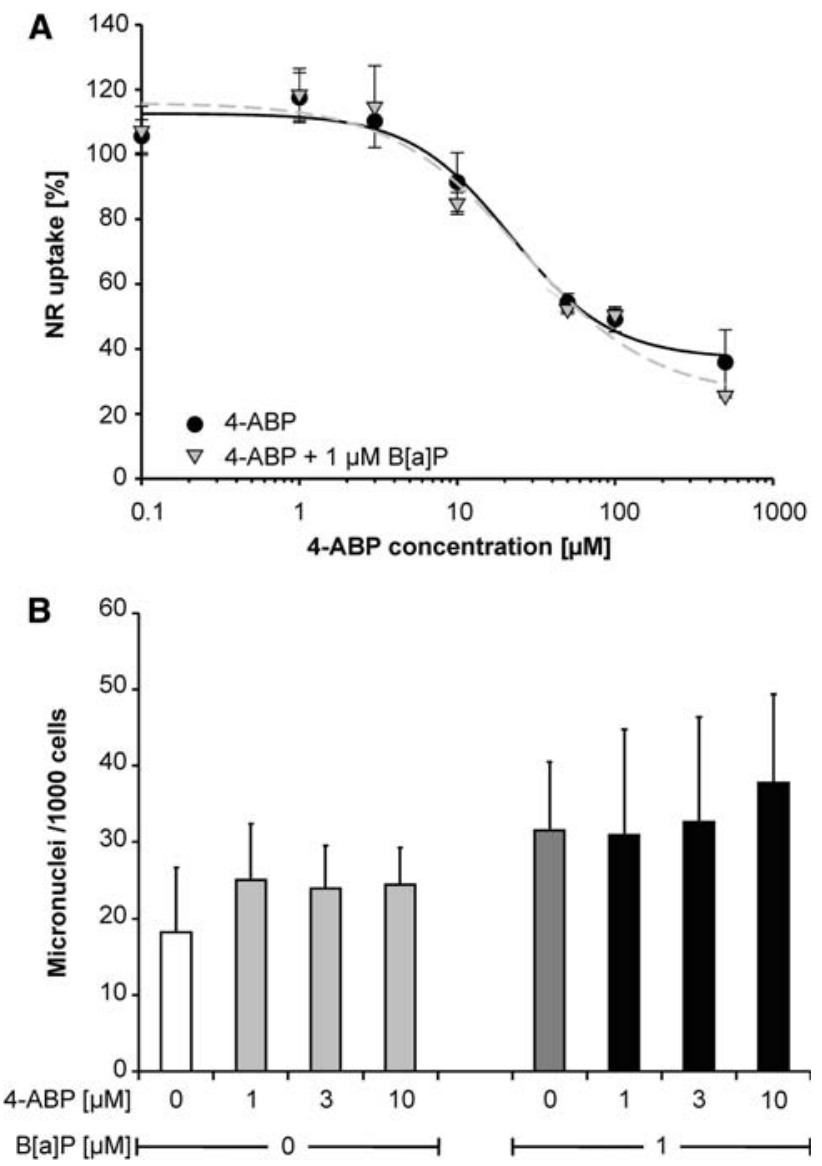

Fig. 3 a Cytotoxicity of 4-ABP alone (circles) and in combination with $1 \mu \mathrm{M} \mathrm{B}[\mathrm{a}] \mathrm{P}$ (triangles) in PUBEC determined with the neutral red uptake assay. PUBEC were treated for $24 \mathrm{~h}$ with the stated concentrations of the test substances. Neutral red uptake is expressed as percent compared to the solvent control $(0.2 \%$ DMSO) which is defined as $100 \%$ uptake. b Induction of micronuclei in PUBEC by 4-ABP (light grey columns), $1 \mu \mathrm{M} \mathrm{B}[\mathrm{a}] \mathrm{P}$ (dark grey column) and 4-ABP in combination with $1 \mu \mathrm{M} \mathrm{B}[\mathrm{a}] \mathrm{P}$ (black columns). The white column represents the solvent control $(0.2 \%$ DMSO). PUBEC were treated for $30 \mathrm{~h}$ with the stated concentrations of the test substances and with the solvent control. Each column represents data from 4 independent PUBEC cultures, $n=4$
Analysis of additional cytochrome $\mathrm{P} 450$ isoforms that are discussed as being relevant in the metabolism of aromatic amines in bladder epithelial cells, namely CYP4B 1 and CYP1B1 (Imaoka et al. 2000; Carnell et al. 2004), did not indicate significant expression changes after incubation with $\mathrm{B}[\mathrm{a}] \mathrm{P}, 4-\mathrm{ABP}$ or combinations of both (data not shown). The same was true for several transcripts related to DNA repair genes as Xeroderma pigmentosum group A protein (XPA), DNA helicase XPB (ERCC3), Xeroderma pigmentosum complementation group $\mathrm{C}$ and $\mathrm{D}$ (XPC, $\mathrm{XPD}$ ), incision specific nuclease ERCC1 and X-ray repair cross-complementing group 1 (XRCC1) (Wood et al. 2001, Sanyal et al. 2004) (results not shown).

\section{Discussion}

In this study, we analysed RNA expression of CYP1A1, COX-2 and UGT1, which are known to be induced via the Ah receptor (Ma and Lu 2007; Kawajiri and Fujii-Kuriyama 2007; Yang and Bleich 2004; Degner et al. 2007; Zhou et al. 2005; Mackenzie et al. 2003). 4-ABP did not induce CYP1A1, COX-2 or UGT1 up to concentrations of $50 \mu \mathrm{M}$. In contrast to 4-ABP, $\mathrm{B}[\mathrm{a}] \mathrm{P}$ is known to be a strong inducer of CYP1A1 which acts via the $\mathrm{Ah}$ receptor (Ma and $\mathrm{Lu}$ 2007). In agreement with the latter studies we also observed an induction of the Ah receptor-dependent genes CYP1A1, COX-2 and UGT1 by B[a]P. Interestingly, induction of these genes by $\mathrm{B}[\mathrm{a}] \mathrm{P}$ was enhanced by coexposure to 4-ABP. This may be relevant, because bladder epithelial cells are frequently co-exposed to aromatic amines and polycyclic aromatic hydrocarbons. Synergistic effects may lead to increased levels of enzymes involved in metabolic activation of bladder carcinogens.

A recent study has shown that bladder epithelial cells of smokers have indeed higher levels of CYP1A1 than cells of non-smokers (Dörrenhaus et al. 2007). The mechanism explaining the interaction between $4-\mathrm{ABP}$ and $\mathrm{B}[\mathrm{a}] \mathrm{P}$ is unknown. The toxicological relevance of the observed interaction between the aromatic amines 4-ABP as well as 2-NA with $\mathrm{B}[\mathrm{a}] \mathrm{P}$ still has to be interpreted with caution. First, we did not observe a synergistic effect concerning cytotoxicity and induction of micronuclei. Second, the concentrations used in this study $(1-50 \mu \mathrm{M}$ for $4-\mathrm{ABP}$ and $1 \mu \mathrm{M}$ for $\mathrm{B}[\mathrm{a}] \mathrm{P}$, are assumedly much higher than in the bladder in vivo, although these concentrations have not been analysed up to now. In such studies DNA adducts of, e.g., 4-ABP were determined in bladder tissue (Kadlubar and Badawi 1995; Vineis et al. 1996).

In conclusion, we have shown that aromatic amines may enhance the induction of Ah receptor-dependent genes by $\mathrm{B}[\mathrm{a}] \mathrm{P}$. Whether this mechanism contributes to bladder carcinogenesis still has to be evaluated. 
Acknowledgments This article is dedicated to the late Jürgen Kuhlmann. We thank C. Nowak, N. Ludwigs, I. Bichbäumer and M. Koch for excellent technical assistance, G. H. Degen for discussion, A. Jung for help in data analysis and A. Wittinghofer for continuous support. Research described in this article was supported by Philip Morris Incorporated (Philip Morris External Research Program).

Competing interest statement The authors declared no competing interests.

Open Access This article is distributed under the terms of the Creative Commons Attribution Noncommercial License which permits any noncommercial use, distribution, and reproduction in any medium, provided the original author(s) and source are credited.

\section{References}

Bonacker D, Stoiber T, Bohm KJ, Unger E, Degen GH, Thier R, Bolt HM (2004) Chromosomal genotoxicity of nitrobenzene and benzonitrile. Arch Toxicol 78:49-57

Brennan P, Bogillot O, Cordier S, Greiser E, Schill W, Vineis P, Lopez-Abente G, Tzonou A, Chang-Claude J, Bolm-Audorff U, Jöckel KH, Donato F, Serra C, Wahrendorf J, Hours M, T'Mannetje A, Kogevinas M, Boffetta P (2000) Cigarette smoking and bladder cancer in men: a pooled analysis of 11 casecontrol studies. Int J Cancer 86:289-294

Brennan P, Bogillot O, Greiser E, Chang-Claude J, Wahrendorf J, Cordier S, Jöckel KH, Lopez-Abente G, Tzonou A, Vineis P, Donato F, Hours M, Serra C, Bolm-Audorff U, Schill W, Kogevinas M, Boffetta P (2001) The contribution of cigarette smoking to bladder cancer in women (pooled European data). Cancer Causes Control 12:411-417

Carnell DM, Smith RE, Daley FM, Barber PR, Hoskin PJ, Wilson GD, Murray GI, Everett SA (2004) Target validation of cytochrome $\mathrm{P} 450 \mathrm{CYP} 1 \mathrm{~B} 1$ in prostate carcinoma with protein expression in associated hyperplastic and premalignant tissue. Int $\mathrm{J}$ Radiat Oncol Biol Phys 58:500-509

Conover WJ, Johnson ME, Johnson MM (1981) A comparative study of tests for homogeneity of variances, with applications to the outer continental shelf bidding data. Technometrics 23:351-361

Countryman PI, Heddle JA (1976) The production of micronuclei from chromosome aberrations in irradiated cultures of human lymphocytes. Mutat Res 41:321-332

Degner SC, Kemp MQ, Hockings JK, Romagnolo DF (2007) Cyclooxygenase- 2 promoter activation by the aromatic hydrocarbon receptor in breast cancer mcf-7 cells: repressive effects of conjugated linoleic acid. Nutr Cancer 59:248-257

Dörrenhaus A, Müller T, Roos PH (2007) Increased CYP1A1 expression in human exfoliated urothelial cells of cigarette smokers compared to non-smokers. Arch Toxicol 81:19-25

Fenech M (1993) The cytokinesis-block micronucleus technique: a detailed description of the method and its application to genotoxicity studies in human populations. Mutat Res 285:35-44

Föllmann W, Behm C, Degen GH (2007) Induction of micronuclei by ochratoxin A is a sensitive parameter of its genotoxicity in cultured cells. Mycotox Res 23:101-109

Föllmann W, Guhe C, Weber S, Birkner S, Mähler S (2000a) Cultured porcine urinary bladder epithelial cells as a screening model for genotoxic effects of aromatic amines: characterisation and application of the cell culture model. ATLA 28:833-854

Föllmann W, Lebrun S, Kullik B, Koch M, Römer HC, Golka K (2000b) Cytotoxicity of ochratoxin A and citrinin in different cell types in vitro. Mycotoxin Res 16:123-127
Guhe C, Degen GH, Schuhmacher US, Kiefer F, Föllmann W (1996) Drug metabolizing enzyme activities in porcine urinary bladder epithelial cell cultures (PUBEC). Arch Toxicol 70:599-606

Guhe C, Föllmann W (1994) Growth and characterization of porcine urinary bladder epithelial cells in vitro. Am J Physiol 266:F298 F308

Green CR, Rodgman A (1996) The tobacco chemists' research conference: a half century forum for advances in analytical methodology of tobacco and its products. Recent Adv Tob Sci 22:131-304

Hecht SS (2003) Tobacco carcinogens, their biomarkers and tobaccoinduced cancer. Nat Rev Cancer 3:733-744

Hollander M, Wolfe DA (1999) Nonparametric statistical methods, 2nd edn. Wiley, New York

Hothorn T, Bretz F, Westfall P (2008) Simultaneous inference in general parametric models. Biom J 50(3):346-363

Hothorn LA, Gerhard D (2008) Statistical evaluation of the in vivo micronucleus assay. Archives of Toxicology (in press)

Imaoka S, Yoneda Y, Sugimoto T, Hiroi T, Yamamoto K, Nakatani T, Funae Y (2000) CYP4B1 is a possible risk factor for bladder cancer in humans. Biochem Biophys Res Commun 277:776-780

International Agency for Research on Cancer (2004) Tobacco Smoke and Involuntary Smoking IARC Monographs on the Evaluation of Carcinogenic Risks to Humans, vol 83. Lyon, France

International Agency for Research on Cancer (1986) Tobacco Smoking, IARC Monographs on the Evaluation of the Carcinogenic Risk of Chemicals to Humans, vol 38. Lyon, France, pp 37-375

Kadlubar FF, Badawi AF (1995) Genetic susceptibility and carcinogen-DNA adduct formation in human urinary bladder carcinogenesis. Toxicol Lett 82-83:627-632

Kawajiri K, Fujii-Kuriyama Y (2007) Cytochrome P450 gene regulation and physiological functions mediated by the aryl hydrocarbon receptor. Arch Biochem Biophys 464:207-212

Kim Y, Park J, Shin YC (2007) Dye-manufacturing workers and bladder cancer in South Korea. Arch Toxicol 81:381-384

Liao J, Xu X, Wargovich MJ (2000) Direct reprobing with anti- $\beta$-actin antibody as an internal control for Western blotting analysis. Bio Techniques 28:216-218

Livak KJ, Schmittgen TD (2001) Analysis of relative gene expression data using real-time quantitative PCR and the 2(-Delta Delta C(T)) Method. Methods 25:402-408

Lovreglio P, Bukvic N, Fustinoni S, Ballini A, Drago I, Foà V, Guanti $\mathrm{G}$, Soleo L (2006) Lack of genotoxic effect in workers exposed to very low doses of 1, 3-butadiene. Arch Toxicol 80:378-381

Ma Q, Lu AY (2007) CYP1A induction and human risk assessment: an evolving tale of in vitro and in vivo studies. Drug Metab Dispos 35:1009-1016

Mackenzie PI, Gregory PA, Gardner-Stephen DA, Lewinsky RH, Jorgensen BR, Nishiyama T, Xie W, Radominska-Pandya A (2003) Regulation of UDP glucuronosyltransferase genes. Curr Drug Metab 4:249-257

Matsuoka A, Yamazaki N, Suzuki T, Hayashi M, Sofuni T (1992) Evaluation of the micronucleus test using a Chinese-Hamster cell-line as an alternative to the conventional invitro chromosomal aberration test. Mutat Res 272:223-236

Paul S, Saha KK (2007) The generalized linear model and extensions: a review and some biological and environmental applications. Environmetrics 18(4):421-443

Plöttner S, Borza A, Wolf A, Bolt HM, Kuhlmann J, Föllmann W (2008a) Evaluation of time-dependence and interindividual differences in benzo[a]pyrene-mediated CYP1A1 induction and genotoxicity in porcine urinary bladder cell cultures. J Toxicol Environ Health A 71:969-975

Plöttner S, Selinski S, Bolt HM, Degen GH, Hengstler JG, Roos PH, Föllmann W (2008b) Distinct subtypes of urinary bladder epithelial cells with inducible and non-inducible cytochrome P450 1A1. Arch Toxicol. doi:10.1007/s00204-008-0329-3 
R Development Core Team (2008) R: a language and environment for statistical computing. R Foundation for Statistical Computing, Vienna

Roos PH (2002) Differential induction of CYP1A1 in duodenum, liver and kidney of rats after oral intake of soil containing polycyclic aromatic hydrocarbons. Arch Toxicol 76:75-82

Sanyal S, Festa F, Sakano S, Zhang Z, Steineck G, Norming U, Wijkström H, Larsson P, Kumar R, Hemminki K (2004) Polymorphisms in DNA repair and metabolic genes in bladder cancer. Carcinogenesis 25:729-734

Smith CJ, Perfetti TA, Garg R, Hansch C (2003) IARC carcinogens reported in cigarette mainstream smoke and their calculated $\log \mathrm{P}$ values. Food Chem Toxicol 41:807-817

Venables WN, Ripley BD (2002) Modern applied statistics with S, 4th edn. Springer, New York

Vineis P, Alavanja M, Buffler P, Fontham E, Franceschi S, Gao YT, Gupta PC, Hackshaw A, Matos E, Samet J, Sitas F, Smith J, Stayner L, Straif K, Thun MJ, Wichmann HE, Wu AH, Zaridze D, Peto R, Doll R (2004a) Tobacco and cancer: recent epidemiological evidence. J Natl Cancer Inst 96:99-106

Vineis P, Alavanja M, Garte S (2004b) Dose-response relationship in tobacco-related cancers of bladder and lung: a biochemical interpretation. Int J Cancer 108:2-7

Vineis P, Talaska G, Malaveille C, Bartsch H, Martone T, Sithisarankul P, Strickland P (1996) DNA adducts in urothelial cells: relationship with biomarkers of exposure to arylamines and polycyclic aromatic hydrocarbons from tobacco smoke. Int J Cancer 65:314-316

Williams DA (1971) A test for differences between treatment means when several dose levels are compared with a zero dose control. Biometrics 27(1):103

Wolf A, Kutz A, Plöttner S, Behm C, Bolt HM, Föllmann W, Kuhlmann $J$ (2005) The effect of benzo(a)pyrene on porcine urinary bladder epithelial cells analyzed for the expression of selected genes and cellular toxicological endpoints. Toxicology 207:255269

Wood RD, Mitchell M, Sgouros J, Lindahl T (2001) Human DNA repair genes. Science 291:1284-1289

Wu CH, Lin HH, Yan FP, Wu CH, Wang CJ (2006) Immunohistochemical detection of apoptotic proteins, p53/Bax and JNK/FasL cascade, in the lung of rats exposed to cigarette smoke. Arch Toxicol 80:328-336

Yang F, Bleich D (2004) Transcriptional regulation of cyclooxygenase-2 gene in pancreatic beta-cells. J Biol Chem 279:3540335411

Zhou J, Zhang J, Xie W (2005) Xenobiotic nuclear receptor-mediated regulation of UDP-glucuronosyl-transferases. Curr Drug Metab 6:289-298 